\title{
PENINGKATAN KEMAMPUAN MEMBUAT RPP TEMATIK MELALUI PELATIHAN BAGI GURU SLB-C SATUAN PENDIDIKAN SDLB SEMESTER II TAHUN PELAJARAN 2017/2018
}

\author{
Dra. Tutik Pudjiastuti, M.M \\ SLB-C TPA Jember \\ Email: tutikpudji99@gmail.com
}

\begin{abstract}
Abstrak
Faktor terpenting keberhasilan pendidikan adalah guru yang professional. Usaha-usaha untuk mempersiapkan guru menjadi profesional telah banyak dilakukan. Kenyataan menunjukkan bahwa tidak semua guru memiliki kinerja yang baik dalam melaksanakan tugasnya. Masalah yang terjadi di SDLB-C TPA Jember yaitu masih ditemukan adanya guru yang kurang maksimal dalam menyusun RPP Tematik. Dengan keadaan demikian, peneliti sebagai pembina sekolah berusaha untuk memberi alternatif solusi, yaitu melalui metode pelatihan. Penelitian ini menggunakan desain Penelitian Tindakan Sekolah (PTS). Penelitian ini bertempat di SDLB-C TPA Jember. Penelitian ini dilaksanakan pada tanggal 01-28 Februari 2018 kepada guru yang berjumlah 7 orang. Hasil penelitian ini menemukan bahwa pelatihan dapat meningkatkan kemampuan guru dalam menyusun RPP Tematik yang inovatif dan lengkap. Hal itu dapat dibuktikan dari hasil observasi/pengamatan yang memperlihatkan bahwa terjadi peningkatan kemampuan guru dalam menyusun RPP Tematik dari siklus ke siklus. Pada siklus I nilai rata-rata komponen RPP 69\% dan pada siklus II 83\%. Jadi, terjadi peningkatan 14\% dari siklus I.
\end{abstract}

Kata Kunci: Kemampuan Guru, RPP Tematik, Pelatihan

\section{PENDAHULUAN}

Faktor terpenting keberhasilan pendidikan adalah guru yang professional. Usaha-usaha untuk mempersiapkan guru menjadi profesional telah banyak dilakukan. Kenyataan menunjukkan bahwa tidak semua guru memiliki kinerja yang baik dalam melaksanakan tugasnya. Proses pengembangan kinerja guru terbentuk dan terjadi dalam kegiatan belajar mengajar di tempat mereka bekerja. Selain itu kinerja guru dipengaruhi oleh hasil pembinaan dan supervisi kepala sekolah (Pidarta, 1992). Pada pelaksanaannya menuntut kemampuan baru pada guru untuk dapat mengelola proses pembelajaran secara efektif dan efisien. Tingkat produktivitas sekolah dalam memberikan pelayananpelayanan secara efisien kepada peserta didik dan masyarakat akan sangat tergantung pada kualitas gurunya yang terlibat langsung dalam proses pembelajaran dan keefektifan mereka dalam melaksanakan tanggung jawab individual dan kelompok.

Dengan demikian, guru sebagai fasilitator yang mengelola proses pembelajaran di kelas mempunyai andil dalam menentukan kualitas pendidikan. Konsekuensinya adalah guru harus merencanakan segala sesuatu agar proses pembelajaran di kelas berjalan dengan efektif. Perencanaan pembelajaran merupakan langkah yang sangat penting sebelum pelaksanaan pembelajaran. Perencanaan yang matang diperlukan 
supaya pelaksanaan pembelajaran berjalan secara efektif. Perencanaan pembelajaran dituangkan ke dalam Rencana Pelaksanaan Pembelajaran (RPP) atau beberapa istilah lain seperti desain pembelajaran, skenario pembelajaran. RPP ini memuat KD, indikator yang akan dicapai, materi yang akan dipelajari, metode pembelajaran, langkah pembelajaran, media pembelajaran, dan sumber belajar serta penilaian pembelajaran.

Berdasarkan observasi awal, masalah yang terjadi di SLB-C TPA Jember yaitu masih ditemukan adanya guru yang tidak bisa memperlihatkan RPP yang dibuat dengan alasan ketinggalan di rumah dan bagi guru yang sudah membuat RPP masih ditemukan adanya guru yang belum melengkapi komponen tujuan pembelajaran dan penilaian (soal, skor dan kunci jawaban), serta langkahlangkah kegiatan pembelajarannya masih dangkal.

Masalah yang lain yaitu sebagian guru di SLB-C TPA Jember belum mendapatkan pelatihan pengembangan RPP Tematik. Selama ini guru-guru yang mengajar sedikit/jarang mendapatkan kesempatan untuk mengikuti berbagai Diklat Peningkatan Profesionalisme Guru. Hal ini menyebabkan banyak guru yang belum tahu dan memahami pengembangan RPP Tematik secara baik dan inovatif. Beberapa guru mengadopsi RPP Tematik milik orang lain. Hal ini peneliti ketahui pada saat mengadakan supervisi akademik. Permasalahan tersebut berpengaruh besar terhadap pelaksanaan proses pembelajaran di kelas.

Dengan keadaan demikian, peneliti sebagai pembina sekolah berusaha untuk memberi alternatif solusi, yaitu melalui metode pelatihan. Pelatihan dapat dipandang secara sempit dan luas. Para peserta pelatihan akan mempelajari pengetahuan dan keterampilan yang sifatnya praktis untuk tujuan tertentu. Pelatihan haruslah terencana, terintegrasi, dan cermat untuk menghasilkan pemahaman dan keterampilan yang diperlukan untuk meningkatkan kinerja organisasi (Sumantri dkk, 2014)

$$
\text { Pelatihan adalah proses }
$$

pendidikan jangka pendek yang menggunakan cara dan prosedur yang sistematis dan terorganisir. Proses yang dimaksud agar peserta mencapai kemampuan tertentu dalam mencapai tujuan organisasi. Para peserta pelatihan akan mempelajari pengetahuan dan keterampilan yang sifatnya praktis untuk tujuan tertentu. Proses dalam pelatihan haruslah terencana, terintegrasi, dan cermat untuk menghasilkan pemahaman dan keterampilan yang diperlukan untuk meningkatkan kinerja organisasi (Napitulu, 2014).

\section{Rencana}

Pelaksanaan

Pembelajaran (RPP) Tematik harus dibuat dengan baik dan benar agar kegiatan pembelajaran berjalan sistematis dan mencapai tujuan pembelajaran. Tanpa RPP Tematik, biasanya pembelajaran menjadi tidak terarah. Oleh karena itu, guru harus mampu menyusun RPP Tematik 
dengan lengkap berdasarkan silabus yang disusunnya. Rencana Pelaksanaan Pembelajaran sangat penting bagi seorang guru karena merupakan acuan dalam melaksanakan proses pembelajaran. Oleh karena itu, sangat penting untuk dilakukan tindakan sekolah dengan judul: "Peningkatan Kemampuan Membuat RPP Tematik Melalui Pelatihan Bagi Guru SLB-C Satuan Pendidikan SDLB Semester II Tahun Pelajaran 2017/2018.”

Philip Combs menyatakan bahwa perencanaan program pembelajaran merupakan suatu penetapan yang memuat komponen-komponen pembelajaran secara sistematis. Analisis sistematis merupakan proses perkembangan pendidikan yang akan mencapai tujuan pendidikan agar lebih efektif dan efisien disusun secara logis, rasional, sesuai dengan kebutuhan siswa, sekolah, dan daerah (masyarakat). Menurut (Suparlan, 2005) perencanaan program pembelajaran adalah hasil pemikiran, berupa keputusan yang akan dilaksanakan. Selanjutnya, Oemar Hamalik menyatakan, bahwa perencanaan program pembelajaran pada hakekatnya merupakan perencanaan program jangka pendek untuk memperkirakan suatu proyeksi tentang sesuatu yang akan dilakukan dalam kegiatan pembelajaran.

$$
\text { Penelitian Tindakan Sekolah }
$$
(PTS) ini bertujuan untuk meningkatkan kemampuan guru dalam membuat RPP Tematik melalui pelatihan bagi guru SLB-C Satuan
Pendidikan SDLB Semester II Tahun Pelajaran 2017/2018.

Berdasarkan pendapat di atas dapat disimpulkan bahwa Perencanaan Pelaksanaan Pembelajaran (RPP) adalah suatu upaya menyusun perencanaan pembelajaran yang akan dilaksanakan dalam kegiatan pembelajaran untuk mencapai tujuan yang telah ditetapkan dalam kurikulum sesuai dengan kebutuhan siswa, sekolah, dan daerah. Dalam Kurikulum 2018, guru bersama warga sekolah berupaya menyusun kurikulum dan perencanaan program pembelajaran, meliputi: program tahunan, program semester, silabus, dan rencana peleksanaan pembelajaran. Rencana Pelaksanaan Pembelajaran dijabarkan dari silabus untuk mengarahkan kegiatan belajar peserta didik dalam upaya mencapai Kompetensi Dasar. RPP merupakan acuan guru dalam melaksanakan pembelajaran untuk setiap KD. Oleh karena itu, apa yang tertuang di dalam RPP memuat hal-hal yang langsung berkaitan dengan aktivitas pembelajaran dalam upaya pencapaian penguasaan suatu KD.

Menurut Permendiknas No. 41 Tahun 2007, komponen RPP terdiri dari (a) identitas mata pelajaran, (b) standar kompetensi, (c) kompetensi dasar, (d) indikator pencapaian kompetensi, (e) tujuan pembelajaran, (f) materi ajar, (g) alokasi waktu, (h) metode pembelajaran, (i) kegiatan pembelajaran meliputi: pendahuluan, inti, penutup, (j) sumber belajar, (k) penilaian hasil belajar meliputi: soal, skor dan kunci jawaban. 


\section{METODE}

Penelitian ini dilaksanakan di SLB-C TPA Jember dan dilaksanakan selama kurang lebih satu bulan mulai tanggal 01 Februari - 28 Februari 2018. Subyek dalam Penelitian ini adalah guru-guru di SLB-C TPA Jember. Obyek penelitian ini adalah Rencana Pelaksanaan Pembelajaran (RPP) Tematik yang sudah dibuat guru-guru SLB-C TPA Jember.

Teknik pengumpulan data dalam penelitian ini adalah wawancara, observasi, dan diskusi.

a. Wawancara dipergunakan untuk mendapatkan data atau informasi tentang pemahaman guru terhadap RPP Tematik. Wawancara ini menggunakan panduan wawancara untuk mengetahui kemampuan awal yang dimiliki guru tentang RPP Tematik.

b. Observasi dipergunakan untuk mengumpulkan data dan mengetahui kompetensi guru dalam menyusun RPP Tematik dengan lengkap. Peneliti menggunakan lembar observasi untuk mengetahui komponen RPP Tematik yang telah dibuat oleh guru.

c. Diskusi dilakukan antara peneliti dengan guru.Diskusi ini dilakukan dengan maksud untuk sharing pendapat antara peneliti dengan guru.

Penelitian ini berbentuk Penelitian Tindakan Sekolah (School Action Research), yaitu sebuah penelitian yang merupakan kerjasama antara peneliti dan guru, dalam meningkatkan kemampuan guru agar menjadi lebih baik dalam menyusun rencana pelaksanaan pembelajaran. Metode yang digunakan dalam penelitian ini adalah metode deskriptif, dengan menggunakan teknik persentase untuk melihat peningkatan yang terjadi dari siklus ke siklus. Metode deskriptif dapat diartikan sebagai prosedur pemecahan masalah yang diselidiki dengan menggambarkan/melukiskan keadaan subyek/objek penelitian (seseorang, lembaga, masyarakat, dan lain-lain) pada saat sekarang berdasarkan faktafakta yang tampak atau sebagaimana adanya. (Nawawi, 1985) Dengan metode ini peneliti berupaya menjelaskan data yang peneliti kumpulkan melalui komunikasi langsung atau wawancara, observasi/pengamatan, dan diskusi yang berupa persentase atau angkaangka.

Prosedur penelitian adalah suatu rangkaian tahap-tahap penelitian dari awal sampai akhir. Penelitian ini merupakan proses pengkajian sistem berdaur sebagaimana kerangka berpikir yang dikembangkan oleh Suharsimi Arikunto. Prosedur ini mencakup tahap-tahap: (1) perencanaan, (2) pelaksanaan, (3) pengamatan, dan (4) refleksi. Keempat kegiatan tersebut saling terkait dan secara urut membentuk sebuah siklus.Alur Penelitian Tindakan Sekolah (PTS) ini dapat dilihat pada gambar berikut: 


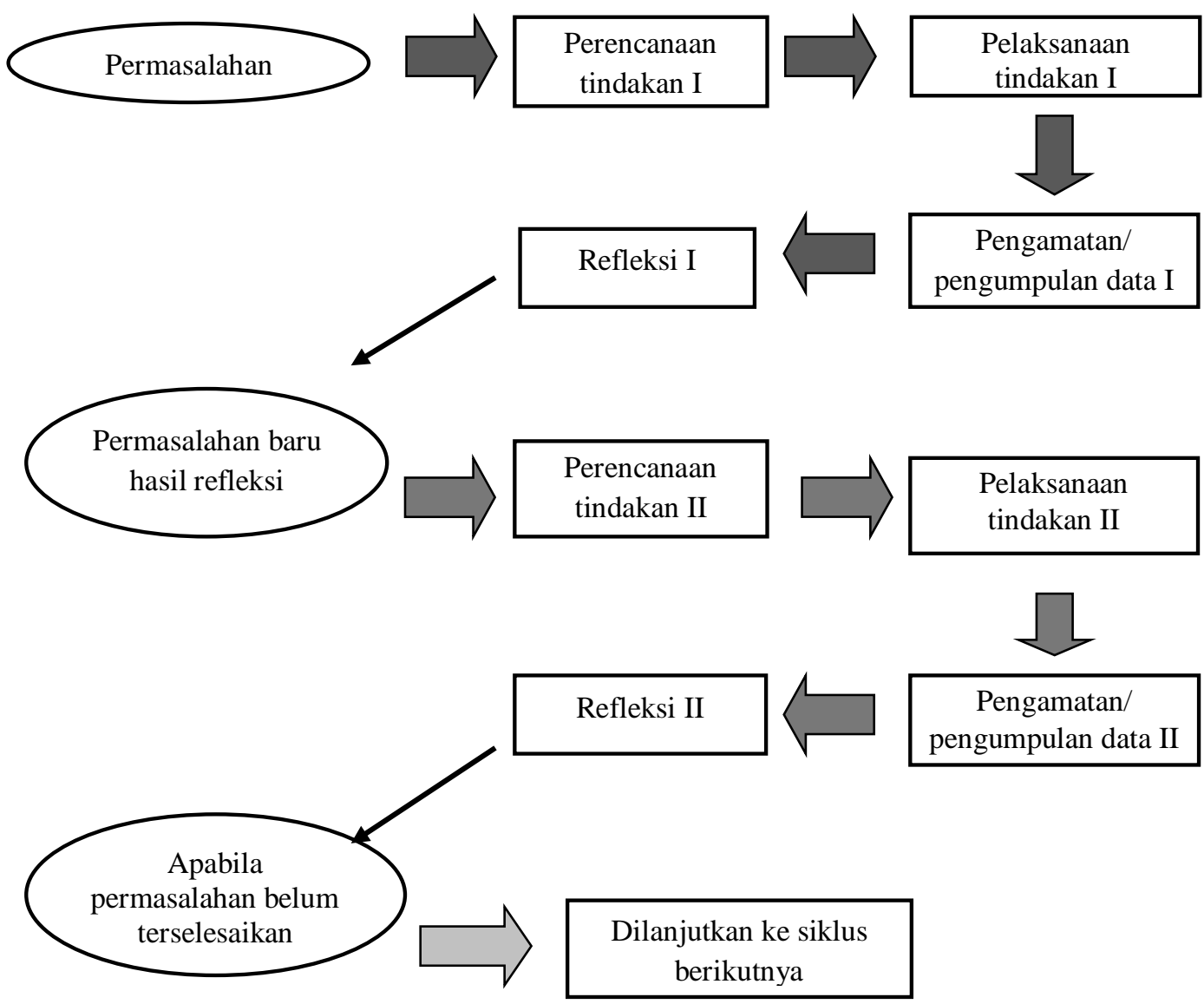

Gambar 1. Alur Penelitian Tindakan Sekolah

Sumber: Tutik (2018) 


\section{HASIL DAN PEMBAHASAN}

Dari hasil wawancara terhadap tujuh orang guru, peneliti memperoleh informasi bahwa guru (tujuh orang) kurang memahami kerangka penyusunan RPP Tematik, hanya sekolah yang memiliki dokumen standar proses (satu buah), hanya dua orang guru yang pernah mengikuti pelatihan pengembangan RPP Tematik, umumnya guru mengadopsi dan mengadaptasi RPP Tematik, kebanyakan guru tidak tahu dan tidak paham menyusun RPP Tematik secara lengkap, mereka setuju bahwa guru harus menggunakan RPP Tematik dalam melaksanakan proses pembelajaran yang dapat dijadikan pedoman dalam proses pembelajaran.

\section{Siklus I (Pertama)}

Siklus pertama terdiri dari empat tahap yakni: (1) perencanaan, (2) pelaksanaan, (3) observasi, dan (4) refleksi seperti berikut ini.

1. Perencanaan (Planning)
a. Membuat lembar wawancara
b. Membuat format/instrumen penilaian RPP Tematik
c. Membuat rekapitulasi hasil penyusunan RPP Tematik siklus I dan II
d. Membuat format rekapitulasi hasil penyusunan RPP
Tematikdari siklus ke siklus

2. Pelaksanaan (Action)

Pada saat awal siklus pertama indikator pencapaian hasil dari setiap komponen RPP Tematik belum sesuai/tercapai seperti rencana/keinginan peneliti. Hal itu dibuktikan dengan masih adanya komponen RPP Tematik yang belum dibuat oleh guru. Masih ada guru yang belum melengkapi RPP-nya baik dengan komponen maupun subsub komponen RPP Tematik tertentu. Satu orang tidak melengkapi RPP-nya dengan komponen indikator pencapaian kompetensi. Untuk komponen penilaian hasil belajar, dapat dikemukakan sebagai berikut:

a. Satu orang tidak melengkapinya dengan teknik dan bentuk instrumen.

b. Satu orang tidak melengkapinya dengan teknik, bentuk instumen, soal, pedoman penskoran, dan kunci jawaban.

c. Dua orang tidak melengkapinya dengan teknik, pedoman penskoran, dan kunci jawaban.

d. Satu orang tidak melengkapinya dengan soal, pedoman penskoran, dan kunci jawaban.

e. Satu orang tidak melengkapinya dengan pedoman penskoran dan kunci jawaban.

Selanjutnya mereka dibimbing dan disarankan untuk melengkapinya. 


\section{Siklus II (Kedua)}

Siklus kedua juga terdiri dari empat tahap yakni: (1) perencanaan, (2) pelaksanaan, (3) observasi, dan (4) refleksi. Hasil observasi pada siklus kedua dapat dideskripsikan berikut ini: Observasi dilaksanakan pada tanggal 09 Februari 2018, terhadap tujuh orang guru. Semuanya menyusun RPP Tematik, tapi masih ada guru yang keliru dalam menentukan kegiatan siswa dalam langkah-langkah kegiatan pembelajaran dan metode pembelajaran, serta tidak memilah/ menguraikan materi pembelajaran dalam sub-sub materi. Untuk komponen penilaian hasil belajar, dapat dikemukakan sebagai berikut:

a. Satu orang keliru dalam menentukan teknik dan bentuk instrumennya.

b. Satu orang keliru dalam menentukan bentuk instrumen berdasarkan teknik penilaian yang dipilih.

c. Satu orang kurang jelas dalam menentukan pedoman penskoran.

d. Satu orang tidak menuliskan rumus perolehan nilai siswa.

Selanjutnya mereka dibimbing dan disarankan untuk melengkapinya.

Penelitian Tindakan Sekolah dilaksanakan di SLB-C TPA Jember terdiri atas delapan guru, dan dilaksanakan dalam dua siklus. Ketujuh guru tersebut menunjukkan sikap yang baik dan termotivasi dalam menyusun RPP Tematik dengan lengkap. Hal ini peneliti ketahui dari hasil pengamatan pada saat melakukan wawancara dan bimbingan penyusunan RPP Tematik. Selanjutnya dilihat dari kompetensi guru dalam menyusun RPP Tematik, terjadi peningkatan dari siklus ke siklus.

\section{Komponen Identitas Mata Pelajaran}

Pada siklus pertama semua guru (tujuh orang) mencantumkan identitas mata pelajaran dalam RPP-nya (melengkapi RPP-nya dengan identitas mata pelajaran). Jika dipersentasekan, 84\%. Lima orang guru mendapat skor 3 (baik) dan dua orang mendapat skor 4 (sangat baik). Pada siklus kedua ketujuh guru tersebut mencantumkan identitas mata pelajaran dalam RPP-nya. Semuanya mendapat skor 4 (sangat baik). Jika dipersentasekan, 100\%, terjadi peningkatan $16 \%$ dari siklus I.

\section{Komponen Kompetensi inti}

Pada siklus pertama semua guru (tujuh orang) mencantumkan kompetensi inti dalam RPP-nya (melengkapi RPP-nya dengan kompetensi inti). Jika dipersentasekan, 81\%. Masingmasing satu orang guru mendapat skor 1, 2, dan 3 (kurang baik, cukup baik, dan baik). Empat orang guru mendapat skor 4 (sangat baik). Pada siklus kedua ketujuh guru tersebut mencantumkan kompetensi inti dalam RPPnya. Satu orang mendapat skor 
3 (baik) dan enam orang mendapat skor 4 (sangat baik). Jika dipersentasekan, 94\%, terjadi peningkatan $13 \%$ dari siklus I.

3. Komponen Kompetensi Dasar

Pada siklus pertama semua guru (tujuh orang) mencantumkan kompetensi dasar dalam RPPnya (melengkapi RPP-nya dengan kompetensi dasar). Jika dipersentasekan, 81\%. Masingmasing satu orang guru mendapat skor 1, 2, dan 3 (kurang baik, cukup baik, dan baik). Empat orang guru mendapat skor 4 (sangat baik). Pada siklus kedua ketujuh guru tersebut mencantumkan kompetensi dasar dalam RPPnya. Satu orang mendapat skor 3 (baik), dan enam orang mendapat skor 4 (sangat baik). Jika dipersentasekan, 94\%, terjadi peningkatan 13\% dari siklus I.

4. Komponen

Indikator

\section{Pencapaian Kompetensi}

Pada siklus pertama tujuh orang guru mencantumkan indikator pencapaian kompetensi dalam RPP-nya (melengkapi RPP-nya dengan indikator pencapaian kompetensi). Sedangkan satu orang tidak mencantumkan/melengkapinya . Jika dipersentasekan, 56\%. Dua orang guru masing-masing mendapat skor 1 dan 2 (kurang baik dan cukup baik). Empat orang guru mendapat skor 3 (baik). Pada siklus kedua ketujuh guru tersebut mencantumkan indikator pencapaian kompetensi dalam RPP-nya. Enam orang mendapat skor 3 (baik) dan satu orang mendapat skor 4 (sangat baik). Jika dipersentasekan, $78 \%$, terjadi peningkatan $22 \%$ dari siklus I.

5. Komponen

Tujuan

Pembelajaran

Pada siklus pertama semua guru (tujuh orang) mencantumkan tujuan pembelajaran dalam RPP-nya (melengkapi RPP-nya dengan tujuan pembelajaran). Jika dipersentasekan, 63\%. Satu orang guru mendapat skor 1 (kurang baik), dua orang mendapat skor 2 (cukup baik), dan empat orang mendapat skor 3 (baik). Pada siklus kedua ketujuh guru tersebut mencantumkan tujuan pembelajaran dalam RPP-nya. Empat orang mendapat skor 3 (baik) dan tiga orang mendapat skor 4 (sangat baik). Jika dipersentasekan, 84\%, terjadi peningkatan 21\% dari siklus I.

\section{Komponen Materi Ajar}

Pada siklus pertama semua guru (tujuh orang) mencantumkan materi ajar dalam RPP-nya (melengkapi RPP-nya dengan materi ajar). Jika dipersentasekan, 66\%. Dua orang guru masing-masing mendapat skor 1 dan 4 (kurang 
baik dan sangat baik), dua orang mendapat skor 2 (cukup baik), dan tiga orang mendapat skor 3 (baik). Pada siklus kedua ketujuh guru tersebut mencantumkan materi ajar dalam RPP-nya. Lima orang mendapat skor 3 (baik) dan dua orang mendapat skor 4 (sangat baik). Jika dipersentasekan, $81 \%$, terjadi peningkatan $15 \%$ dari siklus I.

\section{Komponen Alokasi Waktu}

Pada siklus pertama semua guru (tujuh orang) mencantumkan alokasi waktu dalam RPP-nya (melengkapi RPP-nya dengan alokasi waktu). Semuanya mendapat skor 3 (baik). Jika dipersentasekan, 75\%. Pada siklus kedua ketujuh guru tersebut mencantumkan alokasi waktu dalam RPP-nya. Dua orang mendapat skor 3 (baik) dan lima orang mendapat skor 4 (sangat baik). Jika dipersentasekan, 91\%, terjadi peningkatan $16 \%$ dari siklus I.

\section{Komponen}

Metode

\section{Pembelajaran}

Pada siklus pertama semua guru (tujuh orang) mencantumkan metode pembelajaran dalam RPP-nya (melengkapi RPP-nya dengan metode pembelajaran). Jika dipersentasekan, 72\%. Dua orang guru mendapat skor 2 (cukup baik), empat orang mendapat skor 3 (baik), dan satu orang mendapat skor 4 (sangat baik). Pada siklus kedua ketujuh guru tersebut mencantumkan metode pembelajaran dalam RPP-nya. Satu orang mendapat skor 2 (cukup baik), lima orang mendapat skor 3 (baik), dan satu orang mendapat skor 4 (sangat baik). Jika dipersentasekan, 75\%, terjadi peningkatan 3\% dari siklus I.

9. Komponen

Langkah-

Langkah

Kegiatan

\section{Pembelajaran}

Pada siklus pertama semua guru (tujuh orang) mencantumkan langkah-langkah kegiatan pembelajaran dalam RPP-nya (melengkapi RPP-nya dengan langkah-langkah kegiatan pembelajaran). Jika dipersentasekan,53\%. Enam orang guru mendapat skor 2 (cukup baik), sedangkan satu orang mendapat skor 3 (baik). Pada siklus kedua ketujuh guru tersebut mencantumkan langkah-langkah kegiatan pembelajaran dalam RPP-nya. Satu orang mendapat skor 2 (cukup baik) dan enam orang mendapat skor 3 (baik). Jika dipersentasekan, 72\%, terjadi peningkatan 19\% dari siklus I.

\section{Komponen Sumber Belajar}

Pada siklus pertama semua guru (tujuh orang) mencantumkan sumber belajar dalam RPP-nya (melengkapi RPP-nya dengan sumber belajar). Jika dipersentasekan, 66\%. Tiga 
orang guru mendapat skor 2 (cukup baik), sedangkan empat orang mendapat skor 3 (baik). Pada siklus kedua ketujuh guru tersebut mencantumkan sumber belajar dalam RPP-nya. Satu orang mendapat skor 2 (cukup baik) dan enam orang mendapat skor 3 (baik). Jika dipersentasekan, 69\%, terjadi peningkatan 3\% dari siklus I.

11. Komponen Penilaian Hasil Belajar

Pada siklus pertama semua guru (tujuh orang) mencantumkan penilaian hasil belajar dalam RPP-nya meskipun sub-sub komponennya (teknik, bentuk instrumen, soal), pedoman penskoran, dan kunci jawabannya kurang lengkap. Jika dipersentasekan, 56\%. Dua orang guru masing-masing mendapat skor 1 dan 3 (kurang baik dan baik), dua orang mendapat skor 2 (cukup baik), dan satu orang mendapat skor 4 (sangat baik). Pada siklus kedua ketujuh guru tersebut mencantumkan penilaian hasil belajar dalam RPP-nya meskipun ada guru yang masih keliru dalam menentukan teknik dan bentuk penilaiannya. Enam orang mendapat skor 3 (baik) dan satu orang mendapat skor 4 (sangat baik). Jika dipersentasekan, 78\%, terjadi peningkatan 22\% dari siklus I. Berdasarkan pembahasan penelitian di atas tampah bahwa terjadi peningkatan kompetensi guru dalam menyusun RPP Tematik melalui pelatihan. Pada siklus I nilai rata-rata komponen RPP 69\%, pada siklus II nilai rata-rata komponen RPP 83\%, terjadi peningkatan $14 \%$.

\section{PENUTUP}

\section{Simpulan}

Berdasarkan hasil Penelitian Tindakan Sekolah (PTS) dapat disimpulkan sebagai berikut:Pelatihan dapat meningkatkan kemampuan guru dalam menyusun RPP Tematik yang inovatif dan lengkap.Hal itu dapat dibuktikan dari hasil observasi/pengamatan yang memperlihatkan bahwa terjadi peningkatan kemampuan guru dalam menyusun RPP Tematik dari siklus ke siklus. Pada siklus I nilai rata-rata komponen RPP 69\% dan pada siklus II $83 \%$. Jadi, terjadi peningkatan $14 \%$ dari siklus I.

\section{Saran}

Telah terbukti bahwa dengan Pelatihan dapat meningkatkan motivasi dan kemampuan guru dalam menyusun RPP Tematik. Oleh karena itu, peneliti menyampaikan beberapa saran sebagai berikut:

1. Motivasi yang sudah tertanam khususnya dalam penyusunan RPP Tematik hendaknya terus dipertahankan dan ditingkatkan/dikembangkan.

2. RPP Tematik yang disusun/dibuat hendaknya mengandung komponen- 
komponen RPP Tematik secara lengkap dan baik karena RPP Tematik merupakan acuan/pedoman dalam melaksanakan pembelajaran.

Dokumen RPP Tematik hendaknya dibuat minimal dua rangkap, satu untuk arsip sekolah dan satunya lagi untuk pegangan guru dalam melaksanakan proses pembelajaran.

\section{DAFTAR PUSTAKA}

Arikunto, S. 2006. Prosedur

Penelitian Pendekatan Praktik. Jakarta : Rineka Cipta.

Depdiknas, Standar Kompetensi Guru Sekolah Dasar, (Jakarta: Depdiknas, 2004)

Imron,Ali, Pembinaan Guru di Indonesia. (Malang: Pustaka Jaya, 2000)

Manurung, Suryani dan Effendi Napitupulu, "Pengaruh Strategi Pelatihan dan Tipe Kepribadian terhadap Hasil Pendidikan dan Pelatihan (Diklat) Pengenalan Pemanfaatan TIK.” Jurnal Teknologi dan Informasi dalam Pendidikan, (Vol. 1 No. 2 2014)

Nawawi, Hadari, Metode Penelitian Bidang Sosial. (Yogyakarta: Gadjah Mada University Press, 1985)

Nurhadi, Pembelajaran Kontekstual (Contextual Teaching and Learning/CTL) dan Penerapannya. (Malang:
Universitas Negeri Malang, 2004)

Pidarta,Made, Pemikiran Tentang Supervisi Pendidikan, (Jakarta: Bina Ilmu, 1992)

Pusat Bahasa Pendidikan Nasional. 2003. Kamus Besar Bahasa Indonesia. Jakarta : Balai Pustaka

Sudarsono, Aplikasi Penelitian Tindakan Kelas, (Jakarta: Rineka Cipta, 1999)

Suparlan, Menjadi Guru Efektif. (Yogyakarta: Hikayat Publishing, 2005) 